\title{
Gambaran Kadar Ureum Serum pada Wanita Hamil Normal
}

\author{
${ }^{1}$ Muhammad A. Hajia \\ ${ }^{2}$ Arthur E. Mongan \\ ${ }^{2}$ Mayer F. Wowor
}

\author{
${ }^{1}$ Program Studi Pendidikan Dokter Fakultas Kedokteran Universitas Sam Ratulangi Manado \\ ${ }^{2}$ Bagian Patologi Klinik Fakultas Kedokteran Universitas Sam Ratulangi Manado \\ Email: assabiqunhajia@gmail.com
}

\begin{abstract}
During pregnancy, there are a variety of anatomical, physiological, biochemical, and hormonal changes that greatly affect several organ systems. Functional changes resulted from hormonal changes, increased load due to fetal growth, and ureter obstruction due to uterus enlargement cause increased glomerular filtration rate (GFR) that indicates an increase in renal function. These changes are accompanied by altered plasma concentration of certain substances such as ureum. Increased GFR results in declining plasma urea level. This study was aimed to obtain the serum urea levels in women with normal pregnancy. This was a descriptive observational study. There were 30 blood samples obtained from normal pregnant women in public health centers at Minanga, Bahu, and Sario from October 2017 to November 2017. The results showed that 30 normal pregnant women $(100 \%)$ had decreased serum urea, as follows: $12.33 \mathrm{mg} / \mathrm{dl}$ in the 1st trimester; $9.09 \mathrm{mg} / \mathrm{dl}$ in the 2 nd trimester; and $11,8 \mathrm{mg} / \mathrm{dl}$ in the 3rd trimester. Conclusion: Serum urea of normal pregnant women in the 1st trimester was higher than in the 2nd and 3rd trimester.
\end{abstract}

Keywords: normal pregnancy, urea

\begin{abstract}
Abstrak: Selama kehamilan, wanita mengalami perubahan anatomis, fisiologis, biokimia dan endokrin yang sangat memengaruhi beberapa sistem organ. Perubahan fungsi selama kehamilan karena efek hormonal, peningkatan beban dari janin, dan obstruksi ureter oleh rahim yang semakin membesar mengakibatkan peningkatan Glomerular Filtration Rate (GFR) yang merupakan indikasi peningkatan fungsi filtrasi ginjal disertai perubahan konsentrasi plasma. Sebagai hasil dari peningkatan GFR, ureum plasma menurun pada kehamilan. Penelitian ini bertujuan untuk mengetahui gambaran kadar ureum serum pada wanita hamil normal. Jenis penelitian ialah deskriptif observasional. Terdapat 30 sampel darah dari wanita hamil normal di Puskesmas Minanga, Bahu, dan Sario sejak Oktober-November 2017. Hasil penelitian mendapatkan 30 wanita hamil normal (100\%) mengalami penurunan kadar serum ureum yaitu $12,33 \mathrm{mg} / \mathrm{dl}$ pada trimester I; $9,09 \mathrm{mg} / \mathrm{dl}$ pada trimester II; dan 11,8 $\mathrm{mg} / \mathrm{dl}$ pada trimester III. Simpulan: Ureum serum pada wanita hamil normal trimester 1 lebih tinggi dibandingkan kadar serum ureum trimester 2 dan kadar serum ureum trimester 3.
\end{abstract}

Kata kunci: hamil normal, ureum serum

Menurut Federasi Obstetri Ginekologi Internasional, kehamilan didefinisikan sebagai fertilisasi atau penyatuan dari spermatozoa dan ovum dan dilanjutkan dengan nidasi atau implantasi. Bila dihitung dari saat fertilisasi hingga lahirnya bayi, kehamilan normal akan berlangsung dalam waktu 40 minggu atau 9 bulan 7 hari. Kehamilan terbagi dalam 3 trimester, yaitu trimester pertama berlangsung dalam 12 minggu, trimester kedua berlangsung 15 minggu (minggu ke-13 hingga ke-27), dan trimester ketiga berlangsung 13 minggu (minggu ke-28 hingga ke-40). ${ }^{1}$ Kriteria 
hamil normal yaitu kondisi ibu sehat, tidak ada riwayat kelainan obstetrik, ukuran uterus sesuai dengan usia kehamilan, pemeriksaan fisik dan laboratorium normal. $^{2}$

Selama kehamilan, wanita mengalami perubahan anatomis, fisiologis, biokimia dan endokrin yang sangat memengaruhi beberapa sistem organ, salah satunya ialah ginjal. Ginjal merupakan tempat utama untuk membuang sisa produk-produk hasil metabolisme yang tidak lagi dibutuhkan tubuh termasuk ureum. Akibat perubahan fungsi selama kehamilan karena efek hormonal, peningkatan beban dari janin, dan obstruksi ureter oleh rahim yang semakin membesar terjadi peningkatan Glomerular Filtration Rate (GFR) yang merupakan indikasi peningkatan kerja filtrai ginjal. Perubahan ini disertai dengan perubahan konsentrasi plasma. Sebagai hasil dari peningkatan GFR, ureum plasma menurun pada kehamilan. ${ }^{3,4}$

Hasil penelitian Abraham et al. $^{5}$ mendapatkan penurunan kadar ureum menjadi $15,4 \mathrm{mg} / \mathrm{dl}$ pada 134 wanita hamil dibandingkan 44 wanita tidak hamil (17,3 $\mathrm{mg} / \mathrm{dl})$. Pada wanita hamil 0-12 minggu didapatkan kadar ureum 16,5 mg/dl. Pada 13-24 minggu terjadi peningkatan yang bermakna yaitu $23,2 \mathrm{mg} / \mathrm{dl}$, diikuti pada usia kehamilan 25-40 minggu yaitu 25-36 minggu 14,7 mg/dl, dan 27-40 minggu 13,1 $\mathrm{mg} / \mathrm{dl}$. Penelitian Oluchukwu et al. ${ }^{6}$ menunjukkan bahwa terdapat penurunan kadar ureum serum pada trimester pertama hingga trimester ketiga kehamilan. Penelitian Obodo et al. ${ }^{7}$ menunjukkan bahwa ureum serum pada trimester pertama, trimester kedua dan ketiga secara bermakna lebih rendah pada kelompok hamil daripada kelompok wanita tidak hamil. Dari hasil yang diperoleh dalam penelitian ini, tampak bahwa ureum serum selama trimester ketiga ternyata jauh lebih rendah bila dibandingkan dengan wanita tidak hamil. ${ }^{5-7}$

\section{METODE PENELILTIAN}

Jenis penelitian ini ialah deskriptif observasional. Data kadar serum ureum pada wanita hamil normal diperiksa sejak Oktober-November 2017 di Puskesmas Minanga, Bahu, dan Sario. Sampel penelitian ini ialah 30 sampel darah dari wanita hamil normal dalam kurun waktu yang telah ditentukan.

\section{HASIL PENELITIAN}

Dalam penelitian ini didapatkan sebanyak 30 sampel darah; di antaranya 10 trimester pertama, 10 trimester kedua, dan 10 trimester ketiga. Data yang diperoleh kemudian ditampilkan dalam bentuk tabel. Pada penelitian ini kelompok usia terbesar ialah usia 18-23 tahun dan 24-19 tahun, masing-masing 33,3\% (Tabel 1).

Tabel 1. Hasil distribusi wanita hamil normal berdasarkan usia

\begin{tabular}{cccccc}
\hline Usia & T1 & T2 & T3 & Jumlah & \% \\
\hline $18-23$ & 1 & 4 & 5 & 10 & $33 \%$ \\
$24-29$ & 5 & 3 & 2 & 10 & $33 \%$ \\
$30-34$ & 4 & 2 & 2 & 8 & $27 \%$ \\
$35-38$ & 0 & 1 & 1 & 2 & $7 \%$ \\
Jumlah & 10 & 10 & 10 & 30 & $100 \%$ \\
\hline
\end{tabular}

$\mathrm{T}=$ trimester

Berdasarkan jumlah gravida, yang terbanyak didapatkan ialah gravida $1(47 \%)$ (Tabel 2).

Tabel 2. Hasil distribusi wanita hamil normal berdasarkan gravida

\begin{tabular}{cccccc}
\hline Gravida & T1 & T2 & T3 & Jumlah & \% \\
\hline 1 & 4 & 5 & 5 & 14 & $47 \%$ \\
2 & 4 & 4 & 3 & 11 & $37 \%$ \\
3 & 2 & 1 & 2 & 5 & $17 \%$ \\
Jumlah & 10 & 10 & 10 & 30 & $100 \%$ \\
\hline
\end{tabular}

Hasil distribusi kadar ureum tiap trimester berdasarkan kelompok gravida ditampilkan dalam Tabel 3 sedangkan berdasarkan kelompok usia pada Tabel 4 . Hasil distribusi serum ureum memperlihatkan yang tertinggi pada trimester 1 $(12,33 \mathrm{mg} / \mathrm{dl})$, diikuti oleh trimester $3(11,8$ $\mathrm{mg} / \mathrm{dl}$ ) dan yang terendah pada trimester 2 $(9,49 \mathrm{mg} / \mathrm{dl})$ (Tabel 5). 
Tabel 3. Hasil distribusi kadar ureum tiap trimester berdasarkan kelompok gravida

\begin{tabular}{ccccc}
\hline \multirow{2}{*}{ T } & Kadar & \multicolumn{3}{c}{ Gravida } \\
\cline { 3 - 5 } & serum ureum & $\mathbf{1}$ & $\mathbf{2}$ & $\mathbf{3}$ \\
\hline \multirow{3}{*}{ T1 } & Terendah & 8,1 & 10,3 & 9,3 \\
& Tertinggi & 15,1 & 18,3 & 15,2 \\
& Rerata & 11,8 & 12,9 & 12,3 \\
\hline \multirow{3}{*}{ T2 } & Terendah & 7,3 & 5,5 & - \\
& Tertinggi & 11,1 & 12,8 & - \\
& Rerata & 9,3 & 10,2 & 7,4 \\
\hline \multirow{3}{*}{ T3 } & Terendah & 5,7 & 10,7 & 6,2 \\
& Tertinggi & 16,5 & 19,1 & 11 \\
& Rerata & 10,4 & 16,2 & 8,6 \\
\hline
\end{tabular}

Tabel 4. Hasil distribusi kadar ureum tiap trimester berdasarkan kelompok usia

\begin{tabular}{|c|c|c|c|c|c|}
\hline \multirow{2}{*}{$\mathbf{T}$} & \multirow{2}{*}{$\begin{array}{l}\text { Kadar } \\
\text { serum } \\
\text { ureum }\end{array}$} & \multicolumn{4}{|c|}{ Usia (tahun) } \\
\hline & & $18-23$ & 24-29 & 30-34 & 35-38 \\
\hline \multirow{3}{*}{ T1 } & Terendah & - & 8,1 & 12,3 & - \\
\hline & Tertinggi & - & 18,3 & 15,2 & - \\
\hline & Rerata & 10,8 & 13,0 & 11,9 & - \\
\hline \multirow{3}{*}{$\mathbf{T} 2$} & Terendah & 5,5 & 9,8 & 9 & - \\
\hline & Tertinggi & 11,1 & 12,8 & 12,8 & - \\
\hline & Rerata & 8,3 & 11,2 & 10,9 & - \\
\hline \multirow{3}{*}{ T3 } & Terendah & 5,7 & 10,7 & 6,2 & 7,4 \\
\hline & Tertinggi & 16,5 & 18,8 & 11 & - \\
\hline & Rerata & 10,4 & 14,8 & 10,7 & 19,1 \\
\hline
\end{tabular}

Tabel 5. Hasil distribusi serum ureum

\begin{tabular}{cccc}
\hline Parameter & $\begin{array}{c}\text { T1 } \\
(\mathbf{n}=10)\end{array}$ & $\begin{array}{c}\text { T2 } \\
(\mathbf{n}=10)\end{array}$ & $\begin{array}{c}\text { T 3 } \\
(\mathbf{n}=\mathbf{1 0})\end{array}$ \\
\hline $\begin{array}{c}\text { Serum ureum } \\
(\mathrm{mg} / \mathrm{dL})\end{array}$ & 12,33 & 9,49 & 11,8 \\
\hline
\end{tabular}

\section{BAHASAN}

Penelitian ini dilaksanakan di Puskesmas Minanga, Puskesmas Bahu, dan Puskesmas Sario yang dilaksanakan pada bulan Oktober 2017-November 2017. Terdapat 30 wanita hamil normal yang memenuhi kriteria inklusi.

Berdasarkan data yang diperoleh pada Tabel 12 dapat dilihat bahwa kelompok usia 18-23 (33\%) tahun dan 24-29 (33\%) tahun lebih banyak mengalami kehamilan normal. Hasil penelitian ini sejalan dengan penelitian oleh Abraham et al. ${ }^{5}$ yang mendapatkan kelompok usia 20-25 (42\%) tahun yang mengalami kehamilan normal terbanyak. Hal ini juga selaras dengan penelitian yang dilakukan Oluchukwu et al. ${ }^{6}$ yang menunjukkan bahwa usia 26-30 (32\%) tahun merupakan kelompok terbanyak yang mengalami kehamilan normal. Berdasarkan hasil ini, dapat disimpulkan bahwa kelompok yang paling banyak mengalami kehamilan normal ialah kelompok wanita hamil dengan usia muda.

Bedasarkan data yang di peroleh pada Tabel 3 dapat dilihat bahwa kelompok gravida 1 (47\%) lebih banyak. Hal ini sesuai dengan penelitian yang dilakukan Abraham et al. ${ }^{5}$ yang menunjukkan bahwa gravida $1(40 \%)$ yang lebih banyak. ${ }^{5}$ Berdasarkan pengelompokan pada Tabel 4 dapat dilihat bahwa gravida 3 memiliki nilai ureum terendah. Hasil ini berbeda dengan penelitian Abraham et al. ${ }^{5}$ yang menunjukkan kelompok kehamilan ke-4 yang terendah. Berdasarkan hasil ini terdapat perubahan nilai ureum pada gravid yang berbeda.

Berdasarkan data yang diperoleh pada Tabel 5, didapatkan kelompok usia 18-23 tahun menunjukkan nilai ureum terendah. Hasil ini tidak sejalan dengan penelitian Abraham et al. ${ }^{5}$ yang melaoprkan bahwa kelompok usia dengan nilai ureum terendah ialah kelompok usia 36-40 tahun. Berdasarkan hasil ini didapatkan perubahan pada nilai ureum serum dengan nilai terendah pada usia 18-23 tahun.

Tabel 6 memperlihatkan nilai ureum serum pada trimester 1 dengan kadar 12,33 $\mathrm{mg} / \mathrm{dL}$; trimester 2 dengan nilai ureum serum 9,49 mg/dL; dan trimester 3 dengan nilai ureum serum $11,8 \mathrm{mg} / \mathrm{dL}$. Hasil ini menunjukkan bahwa nilai ureum serum pada kelompok trimester 1 lebih tinggi dibandingkan kelompok trimester 2 dan kelompok trimester 3. Hasil penelitian ini tidak selaras dengan penelitian oleh Abraham et al. ${ }^{5}$ yang mendapatkan kelompok trimester 2 mempunyai nilai ureum serum lebih tinggi dibandingkan dengan kelompok trimester 1 dan kelompok 
trimester 3. Hasil penelitian ini serupa dengan penelitian oleh Oluchukwu et al. ${ }^{6}$ yang menunjukkan kelompok trimester 1 lebih tinggi dibandingkan kelompok trimester 2 dan kelompok trimester 3. Hasil ini menunjukkan bahwa trimesrter kehamilan berpengaruh terhadap nilai ureum serum.

Pada sistem kardiovaskular wanita hamil terjadi peningkatan cardiac output dan peningkatan denyut jantung untuk mengurangi systemic vascular resistance (SVR). Peningkatan cardiac output menyebabkan terjadinya vasodilatasi perifer yang dimediasi oleh faktor yang tergantung endotel (endothelium-dependent) seperti nitrik oksida. Vasodilatasi perifer ini diregulasi oleh estradiol dan menyebabkan penurunan SVR. Penurunan SVR dikombinasikan dengan peningkatan aliran darah ginjal. $^{8}$

Panjang ginjal bertambah 1 sampai 1,5 cm selama kehamilan dan ukurannya kembali selama periode waktu 6 bulan pasca persalinan. Secara keseluruhan, volum ginjal selama kehamilan meningkat hingga $30 \%$. Hal ini disebabkan peningkatan volum vaskular ginjal. ${ }^{9}$

Pada kehamilan terjadi vasodilatasi ginjal yang terjadi bersamaan dengan peningkatan beberapa hormon. ${ }^{9}$ Progesteron berpengaruh pada muskular tuba seperti halnya berpengaruh pada motilitas saluran cerna di samping berpengaruh juga terhadap otot polos arteriol sehingga kapasitas vaskular meningkat dan tahanan perifer menurun. ${ }^{1}$ Progesteron dapat meningkatan Renal Plasma Flow (RPF) dan Glomerular Filtration Rate (GFR) namun tidak dapat menjelaskan besarnya peningkatan yang terlihat pada kehamilan. ${ }^{9}$

Salah satu hormon yang disekresi selama kehamilan selain estrogen dan progestreron yaitu relaksin. ${ }^{10}$ Relaksin adalah hormon yang disekresi oleh korpus luteum ovarium dan jaringan plasenta dan menstimulasi pembentukan endothelin yang berperan sebagai mediasi untuk vasodilatasi pada pembuluh darah ginjal melalui sintesis nitrik oksida. Vasodilatasi pembuluh darah ginjal meningkatkan aliran darah melalui ginjal sehingga GFR dapat meningkat hingga 50\%. Peningkatan GFR menyebabkan peningkatan produksi urin dan ekskresi produk sisa metabolisme tubuh meningkat. ${ }^{11}$ Peningkatan GFR dan RPF dimulai pada awal kehamilan. GFR meningkat pada minggu ke-2 setelah fertilisasi dan $50 \%$ pada trimester kedua yang berakibat peningkatan frekuensi berkemih selama kehamilan sehingga terjadi penurunan ureum serum. ${ }^{5,9}$

Limitasi penelitian ini ialah sebagian sampel berada dalam kelompok usia kehamilan berisiko. Untuk penelitian selanjutnya sebaiknya mengambil sampel dengan usia kehamilan tidak berisiko (20-35 tahun).

\section{SIMPULAN}

Berdasarkan hasil penelitian ini dapat disimpulkan bahwa kadar ureum serum pada trimester 1 lebih tinggi dibandingkan pada trimester 2 dan trimester 3 .

\section{SARAN}

Disarankan untuk mningkatkan jumlah sampel dan waktu penelitian untuk menghindari terjadinya bias dalam penelitian.

Perlu dilakukan penelitian dengan metode analitik dilengkapi wawancara terhadap pasien mengenai intervensi yang telah diberikan yang dapat memengaruhi kadar serum ureum.

\section{DAFTAR PUSTAKA}

1. Sarwono P. Perubahan anatomi dan fisiologi pada perempuan hamil. In: Saifuddin $\mathrm{AB}$ et al, editors. Ilmu Kebidanan (4th ed). Jakarta: Bina Pustaka Sarwono Prawirohardjo, 2009.

2. Safiudin AB. Buku Acuan Nasional Pelayanan Kesehatan Maternal dan Neonatal. Jakarta: YBP-SP, 2002.

3. Das B, Chakma M, Mustafa A, Paul D, Dhar KD. A study on serum urea, creatinine and uric acid levels in normal pregnancy (first and third trimester) in Rohilkhand Region, Uttar Prades. Scholars Journal of Applied Medical Sciences (SJAMS). 2016;4(9A):323641.

4. Sherwood L. Fisiologi Manusia dari Sel ke 
Sistem (8th ed). Jakarta: EGC, 2012.

5. Oluchukwu PO, Bello CA, Ogbe RJ.

Evaluation of changes in renal functions of pregnant women attending antenatal clinic in Vom Plateau State, North-Central Nigeria. Scholars Research Library. 2013;5(4):111-6.

6. Lijji K, Abraham R, Kumari B, Prajisha B. Pattern of changes in the levels of serum urea and creatinine in normal pregnancy and at different periods of gestation. Int J Cur Res. 2015;7(11): 23268-23272.

7. Obodo BN, Ebadan MI, Omijie BE, Agbonghai $\mathrm{C}$, Unune $\mathrm{RR}$. Comparative study of age variations andhuman serum creatinine, urea and uric acid levels in pregnant women at different trimesters of pregnancy. IJBAIR. 2016;5(3):114-9.

8. Pillay SP, Catherine PN, Tolppanen H, Mebazaa A. Physiological changes in pregnancy. Cardiovasc J Afr. 2016; 27(2):89-91.

9. Cheung KL, Lafavette RA. Renal phisiology of pregnancy. US National Library of Medicine National Instutes of Health. 2013;20(3):209-14.

10. Guyton AC, Hall JE. Respon tubuh ibu terhadap kehamilan. In: Ernita I, Ilyas I, Widjajakusumah MD, Tanzil A (editor Bahasa Indonesia). Textbook of Medical Physiology. Buku Ajar Fisiologi Kedokteran (12 th ed). Singapore: Sounders Elsevier, 2014; p. 1094-6. 